\title{
Health effects of passive smoking $\cdot 3$
}

\section{Parental smoking and prevalence of respiratory symptoms and asthma in school age children}

\author{
Derek G Cook, David P Strachan
}

\begin{abstract}
Background - A systematic quantitative review of the evidence relating parental smoking to the prevalence of asthma and respiratory symptoms was conducted amongst school age children.

Methods - Sixty relevant studies were identified after consideration of 1593 articles selected by electronic search of the Embase and Medline databases using keywords relevant to passive smoking in children. The search was completed in April 1997 and identified 25 studies of asthma, 41 of wheeze, 34 of chronic cough, seven of chronic phlegm and six of breathlessness which were included in a quantitative overview.

Results - The pooled odds ratios for either parent smoking were 1.21 (95\% CI 1.10 to 1.34) for asthma, 1.24 (95\% CI 1.17 to 1.31$)$ for wheeze, $1.40(95 \%$ CI 1.27 to 1.53$)$ for cough, $1.35(95 \%$ CI 1.13 to 1.62$)$ for phlegm, and 1.31 (95\% CI 1.08 to 1.59$)$ for breathlessness. Adjustment for confounding had little effect. Evidence of heterogeneity between studies appeared largely explicable by publication bias with a superfluity of small studies with large odds ratios. However, excluding these had little effect on the pooled odds ratios. The prevalence of all symptoms increased with the number of parents who smoked. While maternal smoking had a greater effect than paternal smoking, the effect of father only was clearly significant.

Conclusions - The relationship between parental smoking and respiratory symptoms seems very likely to be causal given statistical significance, robustness to adjustment for confounding factors, consistency of the findings in different countries, and evidence of dose response. The raised risk in households where the father, but not the mother, smoked argues for a postnatal effect.

(Thorax 1997;52:1081-1094)
\end{abstract}

Keywords: parental smoking, tobacco smoke pollution, asthma, children.

UK

D G Cook

D P Strachan

Correspondence to: Dr D G Cook.

The first reports of an adverse effect of parental smoking on respiratory symptoms appeared in the early $1970 \mathrm{~s},{ }^{1-3}$ since when many epidemiological studies have reported on the association of parental smoking and respiratory diseases throughout childhood. The US Environmental Protection Agency Review which was essentially narrative concluded that the evidence causally relating exposure to environmental tobacco smoke at home to respiratory symptoms was very strong amongst preschool children, but less compelling (though statistically significant) in children of school age. A more recent quantitative review ${ }^{5}$ failed to distinguish between different exposures and ages.

In this part of a series of systematic and quantitative reviews of the effect of exposure to environmental tobacco smoke in childhood we summarise the evidence relating to the prevalence of respiratory symptoms and asthma in school age children (5-16 years) as assessed by population surveys. It follows on from our previous review of the effects of parental smoking on lower respiratory illness in infancy and early childhood. ${ }^{6}$ Longitudinal and case-control studies of asthma incidence, prognosis, and severity will be reviewed separately.

\section{Methods}

REVIEW PROCESS

This paper is part of a series of reviews of the respiratory effects of exposure to environmental tobacco smoke in children. For this broader review published papers, letters, and review articles were selected by an electronic search of the Embase and Medline databases using the search strategy described elsewhere. ${ }^{6}$ Briefly, all references to passive smoking were selected by the MESH heading Tobacco smoke pollution and/ or text word combinations (\{passive, second hand, involuntary, parent*, maternal, mother*, paternal, father* or household $\}$ and $\left\{\right.$ smok* $^{*}$, tobacco* or cigarette* $\}$ ) in the title, keywords, or abstract. Papers were then restricted to children by selecting all papers classified as containing data on neonates or children under 18 and/or by relevant text words in the title or abstract. Embase searches were entirely based on text word searches. This search, completed in April 1997, yielded 3625 references of which 1593 contained keywords relevant to res- 
stracts were reviewed and 692 were identified as of possible relevance to the assessment of respiratory health effects.

The 692 articles were reviewed and 100 were identified from their abstracts as potentially containing data relating prevalence of respiratory symptoms or asthma to exposure to environmental tobacco smoke. Thirty nine were excluded for the following reasons: 10 because although data on symptoms and environmental tobacco smoke were collected, no data were ever published, ${ }^{7-16}$ a further seven presented no quantitative estimate of any effects though there was usually a comment on lack of statistical significance ${ }^{17-22}$ or of statistical significance, ${ }^{23}$ one study presented no separate data on children, ${ }^{24}$ three were non-English publications, ${ }^{25-27}$ two publications from a European collaborative study were more clearly presented as part of that, ${ }^{28}{ }^{29}$ five related to studies already included, ${ }^{30-34}$ four studies presented data on other end points, ${ }^{35-38}$ one was based on sharing a room with a smoker, ${ }^{39}$ two were not population based, ${ }^{4041}$ and four publications related to a study from which we could not extract data. ${ }^{42-45}$

Where studies resulted in more than one publication we have used all available information to extract the data we sought. Longitudinal studies were included only where they published prevalence data and each study was included only once, usually based on its initial baseline survey.

Table 1 summarises the characteristics of 60 studies which were included in the quantitative overview; 57 were identified by the search strategy above, a further two were identified from citations in the articles reviewed, ${ }^{150}$ while a "grey literature" publication summarising a pan European study covering 19 centres (largely unpublished) was identified by personal knowledge. ${ }^{101}$

The main aim of this European study ${ }^{101}$ was to investigate the relationship between air pollution and respiratory health in school children. Data were also collected on number of smokers in the children's homes. A standard questionnaire to parents was used based on the WHO questionnaire. ${ }^{105}$ Because of the uniform protocol, the size of the study (some 22000 children), and because only two centres appear ever to have published the passive smoking data in a journal, ${ }^{2829}$ we present the data separately from our review of studies published in peer reviewed journals.

\section{SYMPTOM QUESTIONNAIRES}

With very few exceptions the studies reviewed here are based on data collected by self-completed questionnaires to parents. Inevitably definitions of asthma and symptoms vary and reflect the development of standard questionnaires. Many early studies, particularly in the UK, used the MRC respiratory questionnaire developed for adults. ${ }^{106}$ The two most important characteristics of this questionnaire are (1) that it did not ask about symptoms in a defined period but about whether "a person usually coughed first thing in the morning" (cough usually am) or whether "a child's chest ever sounded wheezy or whistling" (wheeze ever) and (2) if the answer was yes to such a question a second question was usually asked eliciting severity. "Does he/she cough like this on most days or nights for as much as three months each year?" (persistent cough) or "Does he/she get this (wheeze) on most days or nights?" (persistent wheeze). The American Epidemiology Standardisation Project (AESP) built on this but also emphasised whether or not symptoms occurred only with or apart from colds in an attempt to distinguish allergic from non-allergic asthma. ${ }^{107}$ More recently questionnaires have been developed which focus on symptoms in the past 12 months with a number of methods of assessing severity. ${ }^{108}$ We have made explicit the differences in definitions where possible but in many instances no clear definition was given (indicated by a question mark in the tables).

\section{EXPOSURE COMPARISONS}

For each study for a given symptom measure we sought to obtain an odds ratio (rather than relative risk) and its $95 \%$ confidence limits for four exposures: any exposure in the household versus none (or equivalently either parent smokes versus neither smokes); mother only smokes versus neither parent smokes; father only smokes versus neither parent smokes; both parents smoke versus neither smoke. Where a study did not present data for children whose parents did not smoke but cited the effect of mothers smoking (versus father only or neither) and father smoking (versus mother only or neither), this is made clear. Few studies presented data on past exposure including smoking by the mother during pregnancy, but where they did this is discussed.

\section{STATISTICAL METHODS}

In many instances the odds ratio and 95\% confidence limits were given or it was possible to calculate them from the raw data. In a few situations it was necessary to derive an approximate standard error (for the log odds ratio) based on the marginal values of the relevant $2 \times 2$ table. Where data allowed standardisation for age, sex, or occasionally another confounder the Mantel-Haenszel method was used to provide an adjusted value. In situations where odds ratios were given separately for different sexes a pooled odds ratio and 95\% confidence interval was calculated by taking a weighted average (on the log scale) using weights inversely proportional to the variances. Similarly, if odds ratios were given for mother only versus neither, father only versus neither, and both smoke versus neither, a weighted average was taken to produce an estimate for either parent smokes versus neither if the latter could not be derived directly from the published data. In a few instances where number of cigarettes was fitted as a continuous variable in a logistic regression the estimate and its standard error were based on the estimated 
Table 1 List of included studies

\begin{tabular}{|c|c|c|c|c|c|c|c|c|c|c|c|}
\hline $\begin{array}{l}\text { Reference } \\
\text { no. }\end{array}$ & $\begin{array}{l}\text { Year } \\
\text { published }\end{array}$ & Country & Population & $\begin{array}{l}\text { Response } \\
\text { rate }\end{array}$ & Age & $\begin{array}{l}\text { No. in ETS } \\
\text { analyses }\end{array}$ & Asthma & Wheeze & $\begin{array}{l}\text { Chronic } \\
\text { cough }\end{array}$ & $\begin{array}{l}\text { Chronic } \\
\text { phlegm }\end{array}$ & $\begin{array}{l}\text { Breath- } \\
\text { lessness }\end{array}$ \\
\hline 1 & 72 & $\mathrm{UK}$ & All school entrants in St Albans & NA & 5 & 1119 & & & * & & \\
\hline 3 & 74 & $\mathrm{UK}$ & All children at 7 schools in Aylesbury & $93 \%$ & $6-14$ & 2426 & & & * & & \\
\hline 46 & 76 & US & Stratified cluster sample of Tucson homes & $72 \%$ & $0-15$ & 626 & * & * & * & * & \\
\hline 47 & 77 & US & Families with children from 3 towns & NA & $7-18$ & 816 & & * & * & & \\
\hline 48 & 78 & UK & Random sample of Derbyshire schools & $86 \%$ & $11-12$ & 5835 & & & * & & * \\
\hline 49 & 79 & $\mathrm{NZ}$ & Students attending 1 college & $96 \%$ & $12-18$ & 715 & & * & & & \\
\hline 50 & 79 & Japan & Children at 2 schools & $99 \%$ & $6-11$ & 1896 & & * & & & \\
\hline 51 & 80 & US & $\begin{array}{l}\text { Random sample of children at school in East } \\
\text { Boston in } 1974+\text { sibs }\end{array}$ & $42 \%$ & $5-9$ & 383 & & * & * & & \\
\hline 52 & 82 & US & Schools in 3 Arizona communities & $76 \%$ & $8-12$ & 628 & * & * & * & * & \\
\hline $53^{\mathrm{a}}$ & 83 & US & Stratified sample of Pennsylvania schools & $93 \%$ & $5-14$ & 4071 & & * & * & * & \\
\hline 54 & 83 & US & Children attending primary school in Iowa City & $55 \%$ & $6-12$ & 1138 & & & * & & \\
\hline 55 & 84 & UK & 65 schools in Northern England & $\mathrm{NA}$ & $8-19$ & 6988 & & & * & & \\
\hline 56 & 84 & US & 6 cities & NA & $6-9$ & 8380 & & * & * & & \\
\hline 57 & 86 & Israel & Not clear. Near coal fired power station & $86 \%$ & $\begin{array}{l}2 \& 5 \\
\text { grade }\end{array}$ & NA & $*$ & $*$ & * & & * \\
\hline 58 & 86 & Korea & Children in households in Wonsung County & NA & $0-14$ & 3651 & & & $*$ & & \\
\hline 59 & 86 & US & Historical birth cohort & $62 \%$ & $6-10$ & 223 & & * & & & \\
\hline 60 & 86 & UK & Children born in 1976 from 1 general practice & $83 \%$ & $7-8$ & 165 & * & * & * & & \\
\hline 61 & 86 & US & Residents of Tecumseh, Michigan & NA & $0-19$ & 3460 & * & * & * & * & \\
\hline $62^{\mathrm{b}}$ & 88 & UK & 30 primary schools in Edinburgh & $91 \%$ & 7 & 1001 & & * & * & & \\
\hline 63 & 88 & $\mathrm{UK}$ & Stratified sample from 22 areas in England & $75 \%$ & $5-11$ & 5169 & * & * & * & & \\
\hline 64 & 88 & Sweden & 7 areas near Norrkoping & $94 \%$ & $\begin{array}{l}6 \text { mo to } \\
16\end{array}$ & 4990 & & & * & & \\
\hline 65 & 89 & US & 3 North American towns & $>90 \%$ & $7-17$ & 1357 & & * & $*$ & * & * \\
\hline 66 & 89 & Canada & 2 rural communities & $81 \%$ & $7-12$ & 1317 & * & * & * & & \\
\hline $67^{\mathrm{c}}$ & 89 & Canada & $\begin{array}{l}5 \text { rural communities in Ontario, } 5 \text { in } \\
\text { Saskatchewan }\end{array}$ & $81 \%$ & $7-12$ & 4003 & $*$ & $*$ & $*$ & $*$ & \\
\hline 68 & 90 & Netherlands & 9 schools in southeast Holland & $72 \%$ & $6-12$ & 1051 & & * & * & & * \\
\hline 69 & 91 & Australia & 2 schools in a polluted and control area & $72 \%$ & $5-12$ & 602 & & * & & & \\
\hline 70 & 91 & $\mathrm{UK}$ & National stratified sample of children & $>90 \%$ & $5-11$ & 14256 & * & * & $*$ & & \\
\hline 71 & 91 & Canada & Children in 30 communities & 83 & $5-8$ & 14059 & $*$ & $*$ & & & \\
\hline 72 & 92 & Italy & Random sample of schools in 3 areas & $94 \%$ & $7-11$ & 2929 & * & & * & & \\
\hline 73 & 93 & Australia & Stratified sample of 36 schools & $94 \%$ & $8 \& 12$ & 4549 & & * & & & \\
\hline 74 & 93 & Austria & 3 zones of air pollution & $88 \%$ & $6-15$ & 1626 & * & & & & \\
\hline 75 & 93 & Australia & All Tasmanian 7 year olds & $99 \%$ & 7 & 8585 & & * & & & \\
\hline 76 & 93 & Australia & All school children in 2 areas & $86 \%$ & $5-12$ & 787 & & * & & & \\
\hline $77^{\mathrm{d}}$ & 94 & Costa Rica & Stratified random sample of 98 schools & $89 \%$ & $5-17$ & 2534 & * & & & & \\
\hline 78 & 94 & $\mathrm{NZ}$ & All children in town of Kawerau & $82 \%$ & $8-13$ & 708 & & * & & & \\
\hline 79 & 94 & UK & 15 primary schools in 3 areas around Liverpool & $92 \%$ & $5-11$ & 1872 & * & * & & & * \\
\hline 80 & 95 & $\mathrm{NZ}$ & All children in defined area & 85 & $6-14$ & 2614 & * & * & * & & \\
\hline 81 & 95 & Hong Kong & 4 selected schools - Chinese middle class & 89 & $3-10$ & 433 & * & & & & \\
\hline 82 & 95 & Sweden & All schools in 1 area & $97 \%$ & $10-12$ & 665 & & * & * & & \\
\hline 82 & 95 & Poland & 1 school in Konin & $97 \%$ & $10-12$ & 410 & & * & * & & \\
\hline 82 & 95 & Estonia & 11 schools in Tallinn, 4 in Tartu & $96 \%$ & $10-12$ & 1519 & & * & * & & \\
\hline 83 & 95 & Australia & All school entries in South Australia & $73 \%$ & $4-5$ & $14124^{\mathrm{e}}$ & & * & & & \\
\hline $84^{\mathrm{f}}$ & 95 & Israel & 3 towns along coast & $95 \%$ & $\begin{array}{l}\text { Grade } 2 \\
\& 5\end{array}$ & 6822 & $*$ & * & $*$ & & \\
\hline 85 & 95 & Netherlands & 2 primary schools & $88 \%$ & $6-12$ & 470 & & * & * & & * \\
\hline 86 & 95 & $\mathrm{UK}$ & Children registered with large urban GP & $98 \%$ & $3-11$ & 1077 & * & & & & \\
\hline 87 & 95 & Norway & Two valleys in Western Norway & $96 \%$ & $7-13$ & 620 & * & & & & \\
\hline 88 & 95 & US & Stratified cluster sample of all US households & NA & $<18$ & 7578 & & * & & & \\
\hline 89 & 95 & $\mathrm{UK}$ & Primary schools in Aberdeen & NA & $8-13$ & 259 & & & * & & \\
\hline 90 & 96 & US & Birth cohort in Tucson & $78 \%$ & 6 & 987 & & * & * & & \\
\hline 91 & 96 & US & Older children of mothers giving birth in hospitals & $91 \%$ & $1-18$ & 5171 & * & & & & \\
\hline 92 & 96 & U. Arab Rep. & Unclear & $86 \%$ & $6-14$ & 729 & * & & & & \\
\hline 93 & 96 & Poland & Cluster sample of primary schools in 2 towns & $75 \%$ & $7-9$ & 1622 & & & $*$ & & \\
\hline 94 & 96 & Canada & Children in 1 town (Humboldt) & NA & $6-17$ & 892 & * & & & & \\
\hline $95^{\mathrm{g}}$ & 96 & Hong Kong & 17 schools in 2 areas with differing air pollution & $96 \%$ & $10-13$ & 3521 & * & * & & * & \\
\hline 96 & 96 & Jordan & Primary schools in and around Irbid City & $90 \%$ & $6-12$ & 3186 & & * & & & \\
\hline 97 & 97 & $\mathrm{UK}$ & Schools in Scottish Highlands & $85 \%$ & $12 \& 14$ & 1537 & & * & * & & \\
\hline 98 & 97 & Hong Kong & 13 randomly selected schools & NA & $13-14$ & $>3733$ & & * & & & \\
\hline 99 & 97 & Turkey & Random sample of children & $86 \%$ & $7-12$ & 5412 & * & * & & & \\
\hline 100 & 97 & US & Bogalusa Heart Study 1992-4 survey used & NA & $5-17$ & 2975 & * & & & & \\
\hline 101 & 82 & EC Study & 19 European centres & $62-99 \%$ & $6-10$ & 22078 & & * & & & \\
\hline
\end{tabular}

ETS $=$ environmental tobacco smoke; $\mathrm{NA}=$ not available from paper

a Data for standard errors from ref 102.

${ }^{\mathrm{b}}$ Data for cotinine in ref 34 .

${ }^{c}$ Prevalence data from ref 103 .

${ }^{\mathrm{d}}$ Note error in table 3 in this paper.

${ }^{\mathrm{e}}$ No. of families.

${ }^{\mathrm{f}}$ See also ref 104 .

${ }^{g} 1991$ data used.

effect of the average number of cigarettes smoked.

The statistical methods used for meta-analyses have been previously described. ${ }^{6}$ Quantitative meta-analysis was carried out by testing odds ratios for heterogeneity using the technique of Breslow and Day. ${ }^{109}$ Pooled odds ratios were produced using a "random effects" model since, in a number of instances, there was evidence of statistically significant heterogeneity of the passive smoking effect between studies. In practice using a "random" as opposed to "fixed effects" model made little difference to point estimates but produced slightly wider confidence limits.
Results

ANY EXPOSURE VERSUS NONE AND EFFECTS OF ADJUSTMENT FOR POTENTIAL CONFOUNDING VARIABLES

Asthma

Twenty five papers were identified as containing quantitative information (table 2). Most studies have reported on asthma ever (typically a positive response to "Has this child ever had asthma?"). A few have reported on current asthma, usually defined as in the past year, while a few specifically asked if the diagnosis had been made by a doctor. We have included under asthma one study which reported on wheezing consultations with the doctor. ${ }^{60}$ 


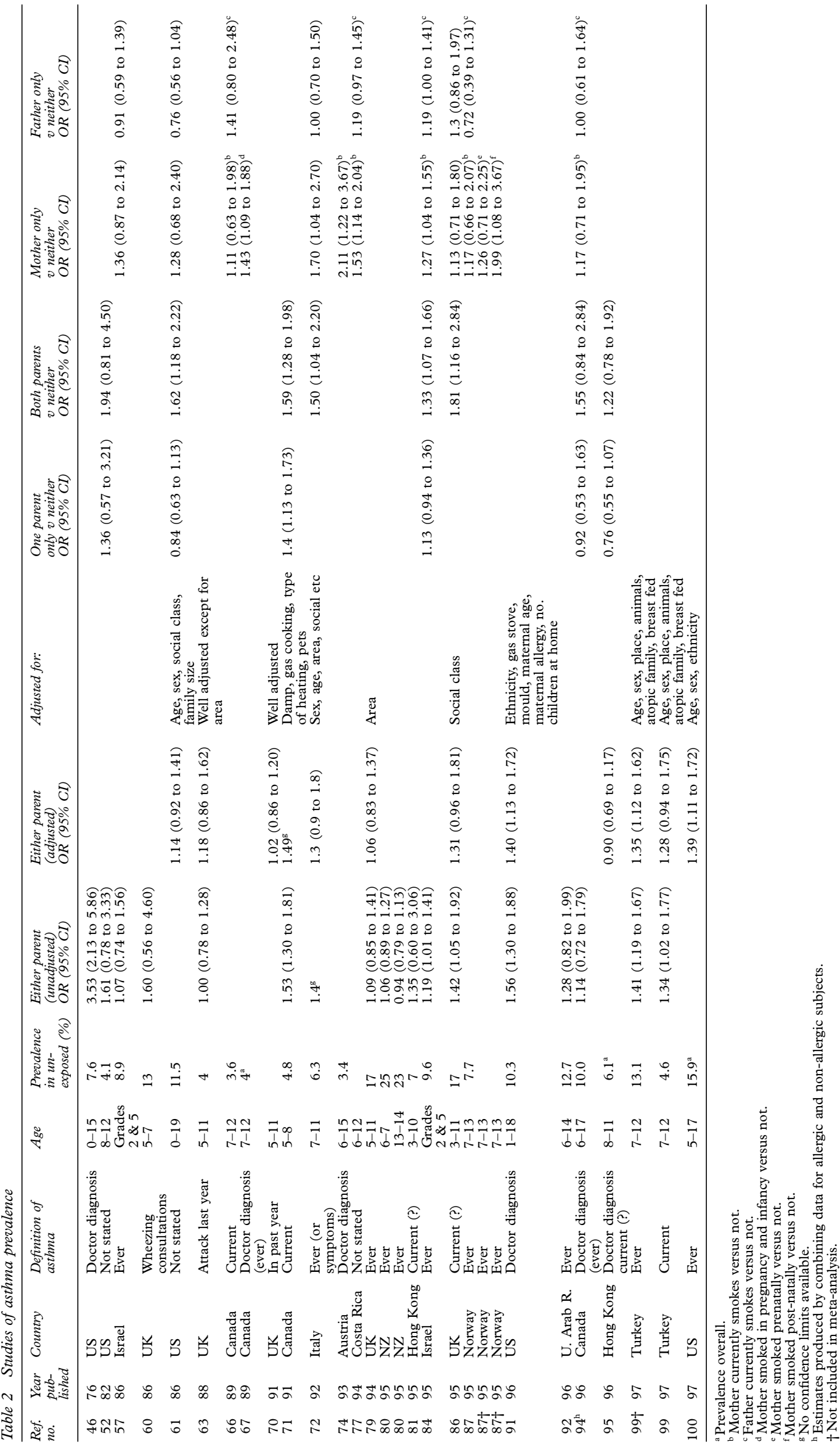




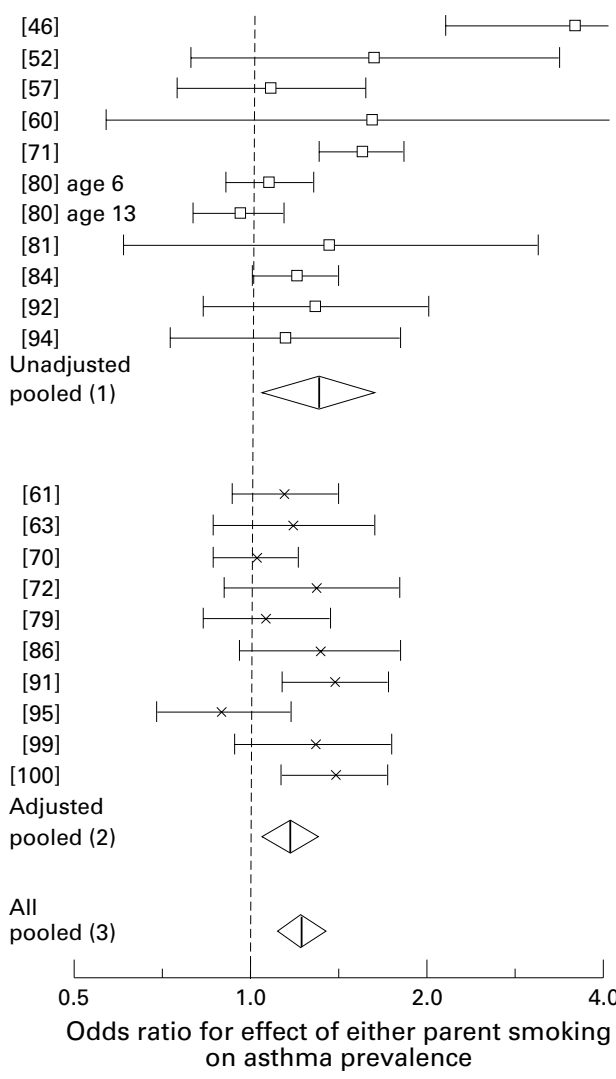

Figure 1 Odds ratios and $95 \%$ confidence limits for the effect of either parent smoking on asthma prevalence: upper part, studies not adjusting for potential confounders contributing to pooled odds ratio (1); lower part, studies adjusting for a variety of potential confounders contributing to pooled odds ratio (2); pooled odds ratio (3) is based on all studies. Studies ordered by date of publication.

The relative odds of asthma in children where either parent smoked compared with that in children where neither smoked is consistently above 1 (only two odds ratios were below $1^{8095}$ ), but the majority of confidence limits include 1. The pooled estimate is 1.21 (95\% CI 1.10 to 1.34), but there is evidence of heterogeneity between studies $\left(\chi_{20}^{2}=49.6, p=0.00025\right)$. It is noticeable that those studies reporting the highest odds ratios were more likely to be early publications, to be small, and not to adjust for confounders (table 2, fig 1). The pooled odds ratio for the unadjusted studies is $1.30(95 \%$ CI 1.04 to $\left.1.62, \chi^{2}{ }_{10}=35.7, p=0.00009\right)$. In contrast, the relative odds for those 10 studies which adjusted for various potential confounders are quantitatively consistent but slightly lower than for the unadjusted studies (pooled OR $=1.18\left(95 \%\right.$ CI 1.05 to $1.31, \chi_{9}^{2}$ for heterogeneity $=13.45, \mathrm{p}=0.14)$. For those seven studies reporting both adjusted and unadjusted odds ratios ${ }^{63717279869199}$ we see very little effect of adjustment (table 2).

Wheeze

Forty one studies were identified with data on wheeze using a variety of definitions (table 3 ) which could broadly be grouped under three headings: wheeze ever, current wheeze, and persistent wheeze.

Of 29 studies reporting the effect of either parent smoking, the two studies with the highest odds ratios reported current persistent wheez $\mathrm{e}^{51}$ and wheeze most days or nights ${ }^{46}$ as opposed to wheeze ever or current wheeze. These two studies also reported the lowest prevalence rates (table 3 ), suggesting that the definitions probably reflected more severe wheeze. In two studies where both wheeze ever and wheeze most days or nights were reported from the same study the odds ratios were greater for wheeze most days or nights. ${ }^{6370}$

As for asthma, all but one of the odds ratios for either parent smoking were above 1 with the highest odds ratios being from small studies which had not adjusted for potential confounders (fig 2). There was clear evidence of heterogeneity of effect amongst the unadjusted studies (pooled odds ratio 1.23 (95\% CI 1.11 to 1.37$), \chi_{15}^{2}$ for heterogeneity $=35.7, \mathrm{p}=$ $0.0019)$. Amongst the adjusted studies the pooled odds ratio was very similar (1.22 (95\% CI 1.16 to 1.29$)$ ) and there was no evidence of heterogeneity $\left(\chi_{13}^{2}=11.7, p=0.55\right)$. For those studies which provided both adjusted and unadjusted odds ratios the effect of adjustment was similarly very small (table 3), except for one early Japanese study. ${ }^{50}$ The overall pooled odds ratio from all studies was 1.24 (table 6).

For the 19 centres participating in the EC study it was possible to extract data for wheeze ever. There was no evidence of heterogeneity between centres $\left(\chi_{18}^{2}=18.6, \mathrm{p}=0.42\right)$ and the pooled odds ratio across the 19 centres was 1.20 (95\% CI 1.09 to 1.32 ).

\section{Chronic cough}

Thirty four studies of cough have been published using a variety of symptom definitions (table 4). While most are based on either the MRC or AESP questionnaires, the largest study invented its own question. ${ }^{55}$ Two recent studies reported raised odds for cough without wheeze, ${ }^{8990}$ emphasising the importance of cough as a symptom. Unlike wheeze, there is no suggestion that the studies reporting the lowest prevalence rates (implying a more restrictive definition) contributed the highest odds ratios. The pooled odds ratio for the 19 studies not adjusting for anything was 1.47 (95\% CI 1.27 to 1.70$), \chi_{18}^{2}$ for heterogeneity $=$ $63.0, \mathrm{p}<0.000001)$, somewhat greater than for those studies adjusting for various factors (pooled OR $=1.30$ (95\% CI 1.19 to 1.41$), \chi_{10}^{2}$ for heterogeneity $=16.6, p=0.84$; fig 3 ). In the three studies reporting both adjusted and unadjusted figures ${ }^{486390}$ the effect of adjustment was small.

\section{Chronic phlegm}

Seven studies reported on phlegm, four using a definition of persistent phlegm and three being unclear (table 5). Three out of six studies reported significant odds ratios for either parent smoking, though all were above 1 (fig 4, top). The pooled odds ratio for either parent smoking 


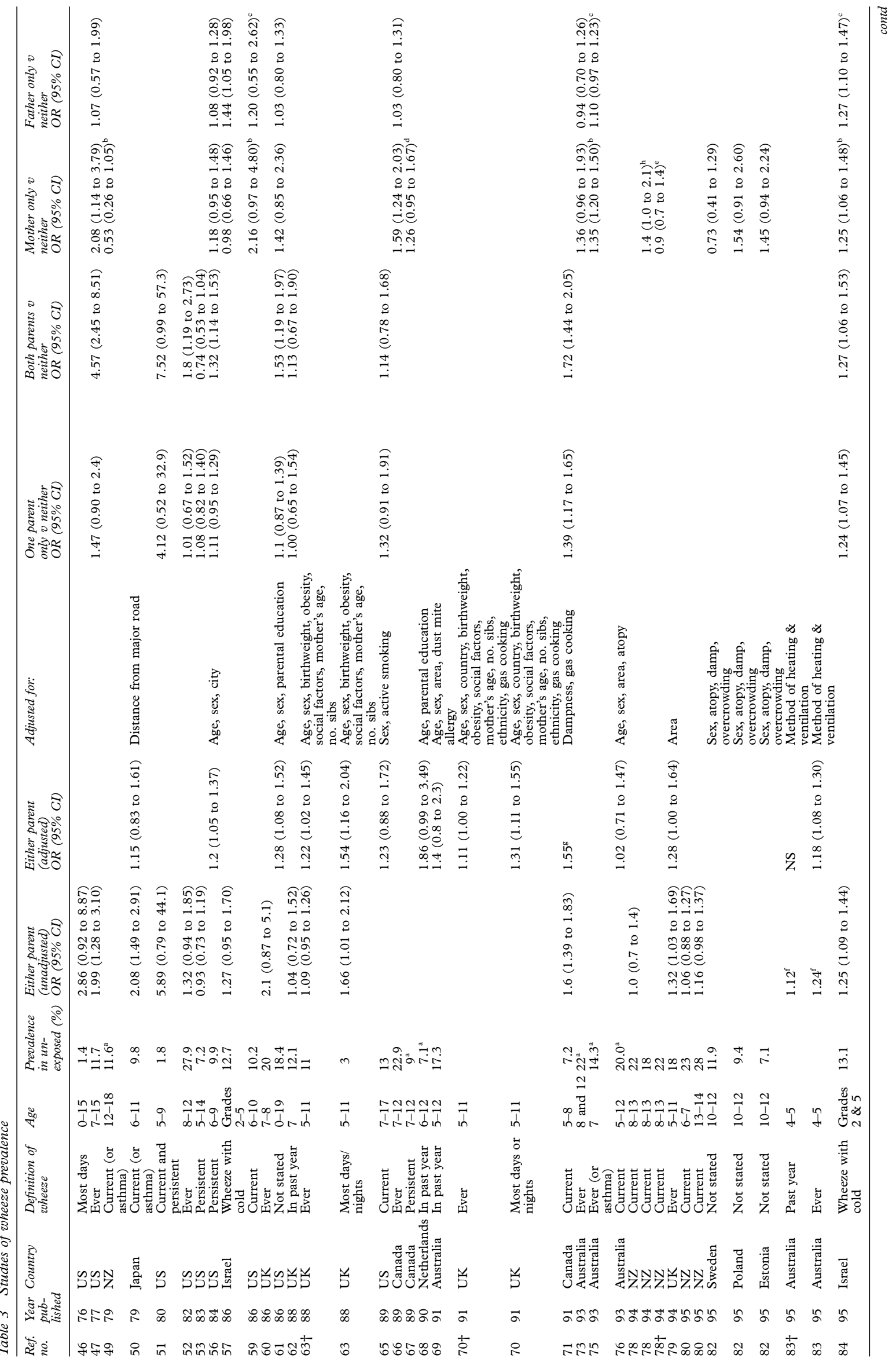




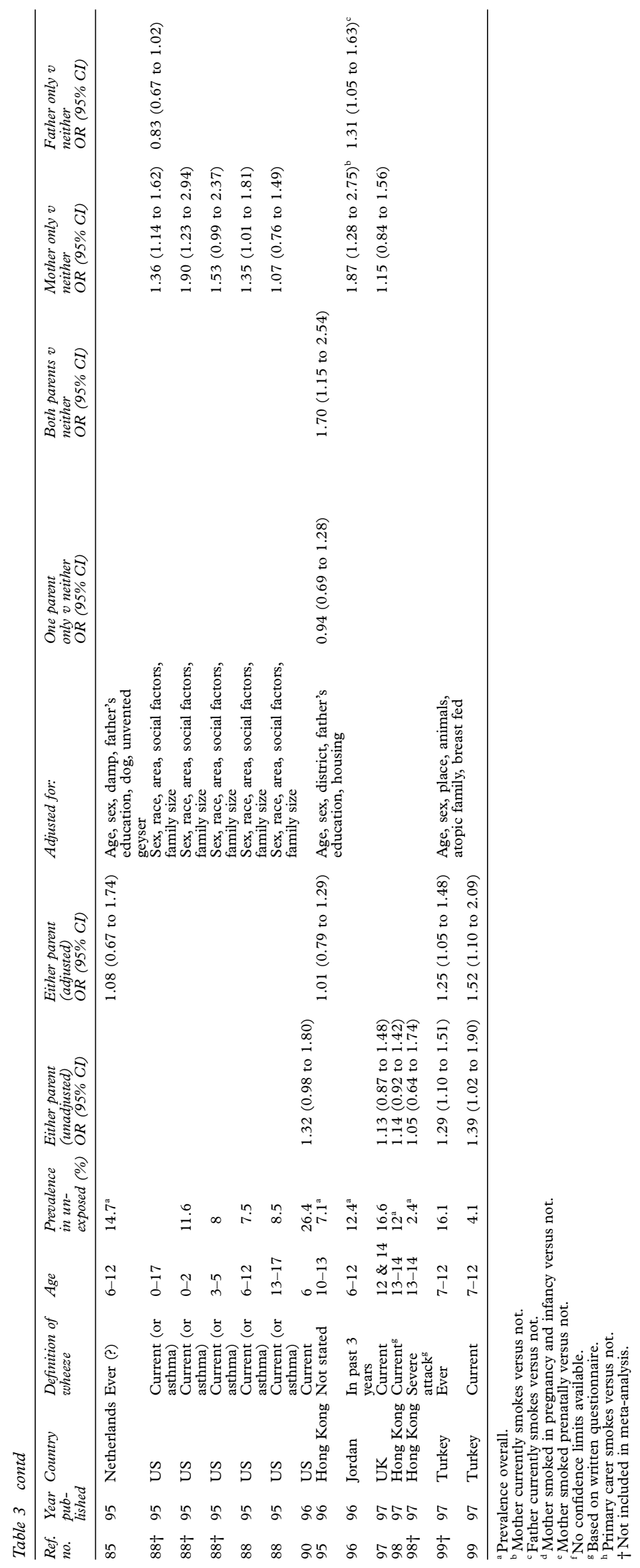




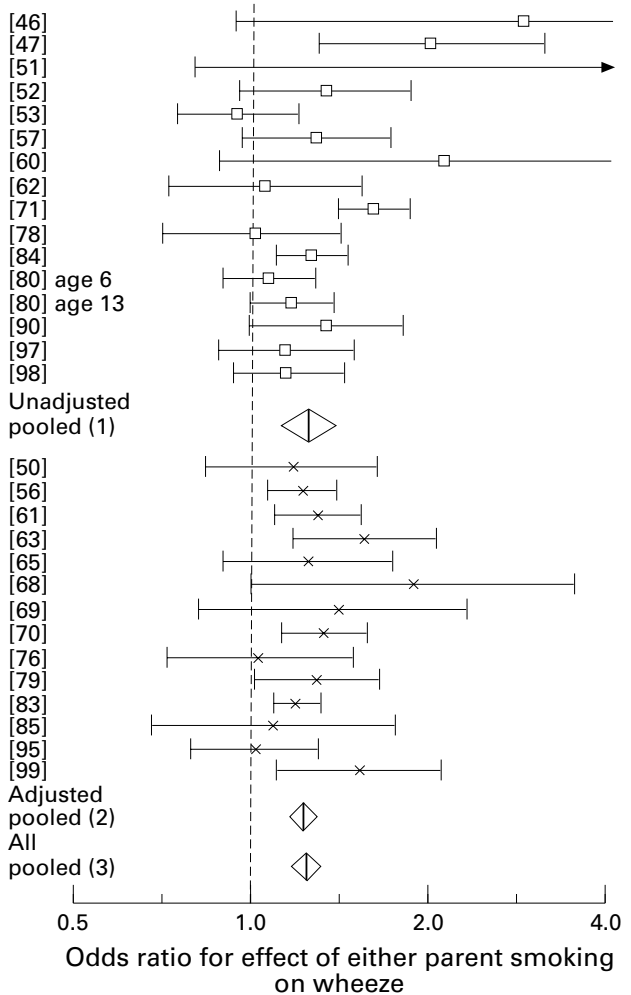

Figure 2 Odds ratios and 95\% confidence limits for the effect of either parent smoking on wheeze prevalence: upper part, studies not adjusting for potential confounders contributing to pooled odds ratio (1); lower part, studies adjusting for a variety of potential confounders contributing to pooled odds ratio (2); pooled odds ratio (3) is based on all studies. Studies ordered by date of publication.

was 1.35 (95\% CI 1.13 to 1.62$)$ with no evidence of heterogeneity between studies $\left(\chi^{2}\right.$ for heterogeneity $=4.3, \mathrm{p}=0.51$ ).

\section{Breathlessness}

Six studies reported on shortness of breath using various definitions (table 5). Only two studies reported statistically significant effects though all bar one of the odds ratios were above 1 (fig 4, bottom). The pooled odds ratio for either parent smoking was 1.31 (95\% CI 1.08 to 1.59$)$ with no evidence of heterogeneity $\left(\chi^{2}{ }_{5}\right.$ for heterogeneity $=4.6, \mathrm{p}=0.47)$.

\section{POOLED ODDS RATIOS}

The pooled odds ratios for smoking by either parent compared with neither are remarkably consistent across different outcomes, ranging from 1.21 for asthma to 1.40 for cough (table 6). For asthma, wheeze, and cough where there are sufficient studies to justify a pooled analysis there is clear evidence of an increased risk of respiratory symptoms if only one parent smokes, whether this is the mother only or the father only. The effect of mother only smoking appears to be greater than that for father only, but a formal comparison of mother only and father only is not possible as it requires within study estimates of standard errors for the cal- culation. There is also clear evidence of dose response with number of parents smoking, the odds ratios for both parents smoking being greater than for one parent only in all cases (table 6).

PASSIVE SMOKING EFFECTS AT DIFFERENT AGES Comparison of different studies is unlikely to give a valid assessment of the risks associated with parental smoking at different ages because of the considerable overlap of age range in many studies as well as different definitions of symptoms. A number of within study comparisons are, however, possible. A large US study found clear evidence of a fall in the odds ratio for current wheeze from 1.9 amongst infants to 1.07 amongst teenagers ${ }^{88}$ (table 3). Similarly, a large questionnaire survey from the UK found a clear fall in the odds ratio for cough from 1.61 at age $8-10$ to 1.50 at $11-13$ to 1.12 at $14-19,55$ while a Korean study ${ }^{58}$ found that the odds ratio for cough in the past two weeks fell from 3.9 under age 5 to 2.6 at ages $6-11$ to 2.0 at ages $12-14$ (table 4 ). In contrast, a relatively small New Zealand study found slightly greater odds ratios for current wheeze and for cough at 13-14 years than at age 6-7 (tables 3 and 4 ). ${ }^{80}$

\section{PAST EXPOSURE}

Few studies have analysed the effects of past as opposed to current exposure. In one of the early studies Colley ${ }^{3}$ reported that prevalence of cough during the day or at night was slightly lower in children of ex-smokers (14.2\% of 634$)$ than in the offspring of never-smokers $(15.6 \%$ of 320). More recently a New Zealand study ${ }^{78}$ found that smoking by the current primary carer was associated with current wheeze (odds ratio $=1.4(95 \%$ CI 1 to 2.1$)$ ) whereas maternal smoking during pregnancy was not (odds ratio $=0.9(95 \%$ CI 0.7 to 1.4$))$. A Norwegian study $^{87}$ found that postnatal smoking by the mother was more strongly related to asthma than either prenatal or current smoking (table 2). A recent Scottish study ${ }^{97}$ reported slightly stronger effects for current maternal as opposed to maternal antenatal smoking for both wheeze (odds ratios 1.15 versus 1.10) and cough (1.93 versus 1.42 )

\section{Discussion}

CONSISTENCY OF EVIDENCE ACROSS DIFFERENT SYMPTOMS

We have found a clear relationship between parental smoking and the prevalence of asthma and respiratory symptoms in school children which is very unlikely to be due to chance alone. The magnitude of the effects is similar for the different outcome measures and, with few exceptions, is consistent across studies and in different countries. The estimated effects were robust to adjustment for a wide range of environmental factors, particularly for wheeze. We conclude that residual confounding is unlikely to be an issue. While there is clear evidence of publication bias, with a lack of small 


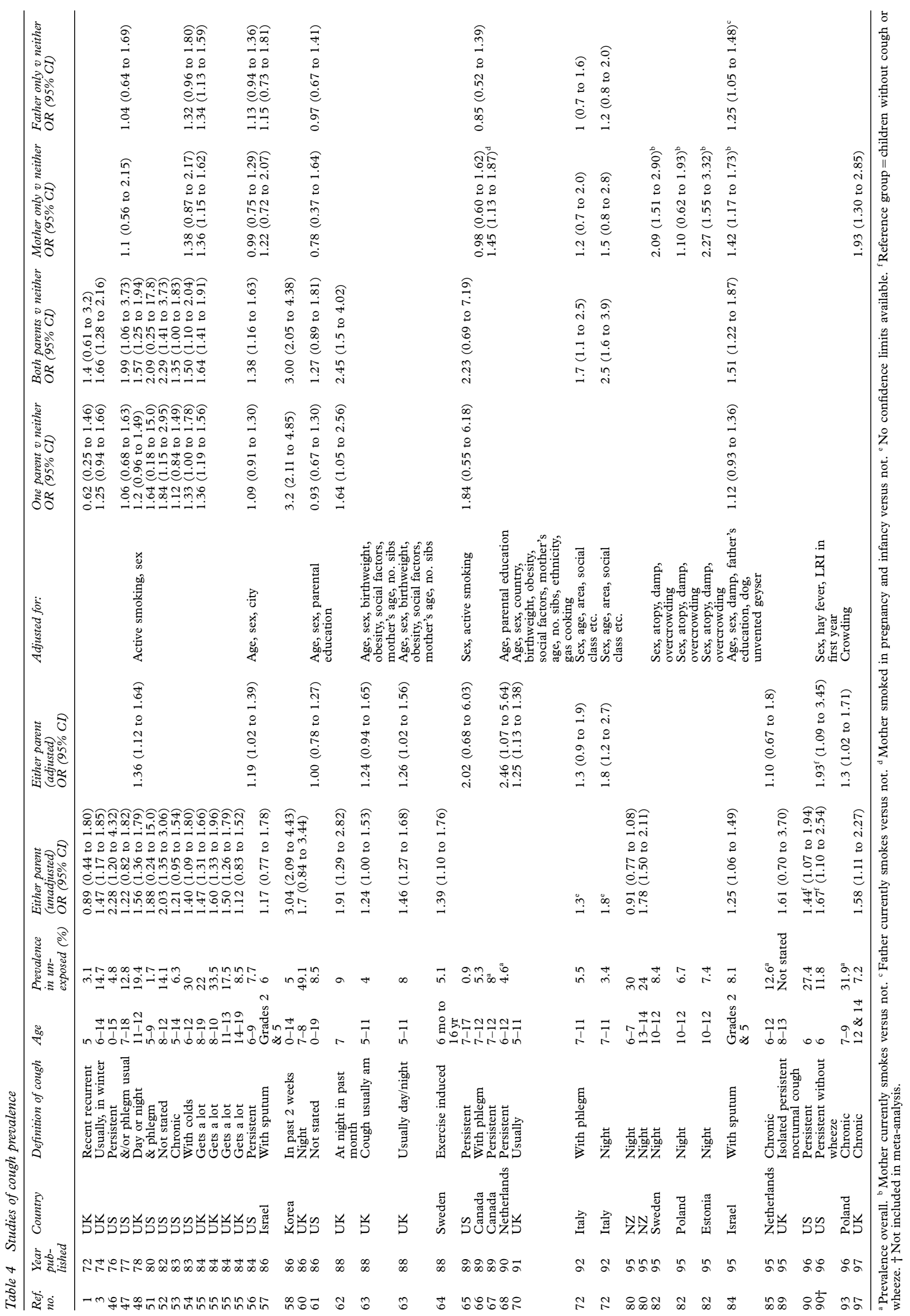




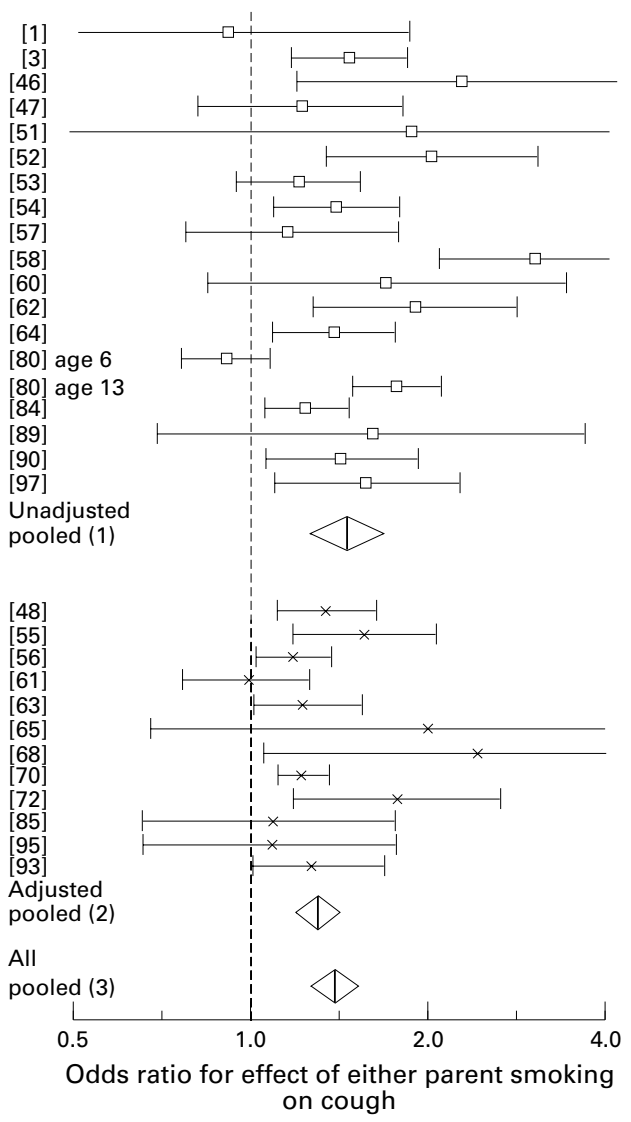

Figure 3 Odds ratios and 95\% confidence limits for the effect of either parent smoking on cough prevalence: upper part, studies not adjusting for potential confounders contributing to pooled odds ratio (1); lower part, studies adjusting for a variety of potential confounders contributing to pooled odds ratio (2); pooled odds ratio (3) is based on all studies. Studies ordered by date of publication.

negative studies, the effect of this on the pooled odds ratios is very slight as so many large studies have been published. The similarity between the pooled odds ratio for wheeze from published studies and in the EC study is further reassurance that the association is not an artefact of selective publication. It is, however, interesting that the two centres which published data in journals (Middlesborough ${ }^{28}$ and $\mathrm{Ar}-$ dennes $^{29}$ ) had above average odds ratios of 1.36 and 1.37 , respectively.

DOSE RESPONSE

Evidence for a causal interpretation is further strengthened by the clear increase in odds with number of parents smoking which is highly statistically significant for asthma, wheeze, and cough and consistently seen in nearly all studies. The effect of mother smoking appears greater than the effect of father only, but there is nevertheless clear evidence for a small effect from paternal smoking. The greater effect of maternal smoking is consistent with the greater effects of maternal smoking on children's cotinine levels at school age. ${ }^{110}$ Given that postnatal exposure from the mother is greater than from the father, and we find evidence of an

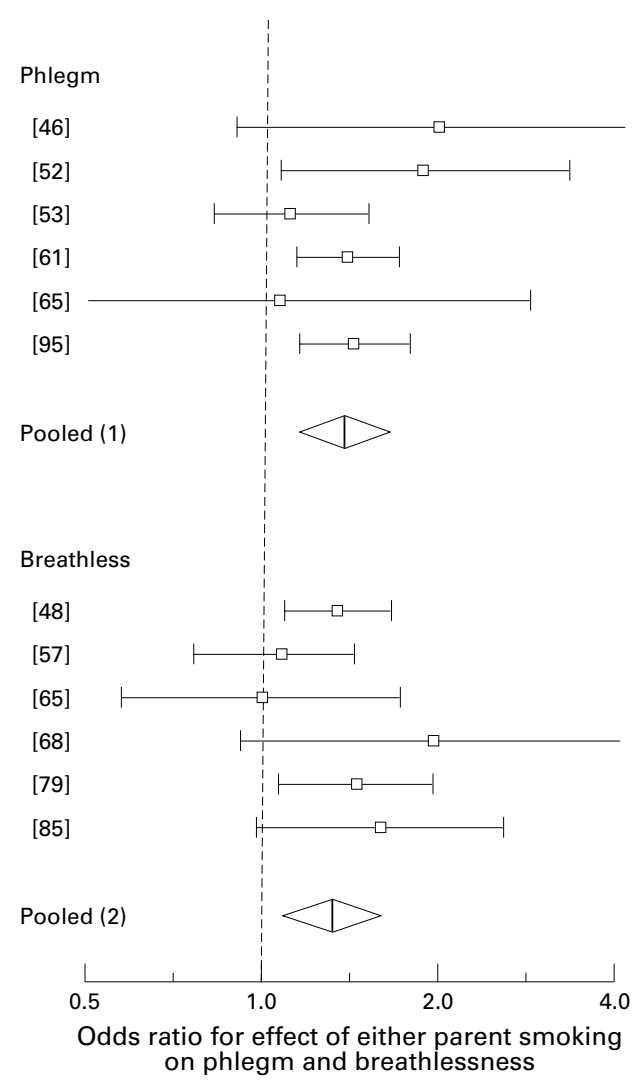

Figure 4 Odds ratios and 95\% confidence limits for the effect of either parent smoking on: upper part: phlegm (adjusted and non-adjusted) contributing to pooled odds ratio (1); lower part, shortness of breath (adjusted and non-adjusted) contributing to pooled odds ratio (2).

Studies ordered by date of publication.

effect from the father only smoking, much of the maternal effect is probably postnatal. Surprisingly few studies have examined number of cigarettes per day and looked for dose response trends amongst exposed children (as opposed to looking for a trend with non-exposed children included), but it seems likely that the greater effect seen amongst children in households where both parents smoke is due to both heavier smoking by the mother as well as the father.

EFFECTS OF PARENTAL SMOKING IN THE PAST On balance the limited evidence suggests that the prevalence of respiratory symptoms is not raised amongst children of ex-smokers ${ }^{378}$ and is more closely related to current maternal smoking than to prenatal smoking by the mother. ${ }^{8797}$ While compatible with the hypothesis that current rather than past exposure is what matters, the evidence is not overwhelming since so few data have been published and exsmokers are likely to have been lighter smokers. The major limitation of all these studies is that the exposure data were not collected prospectively and recall bias is a potential problem. This issue would be better addressed by looking 


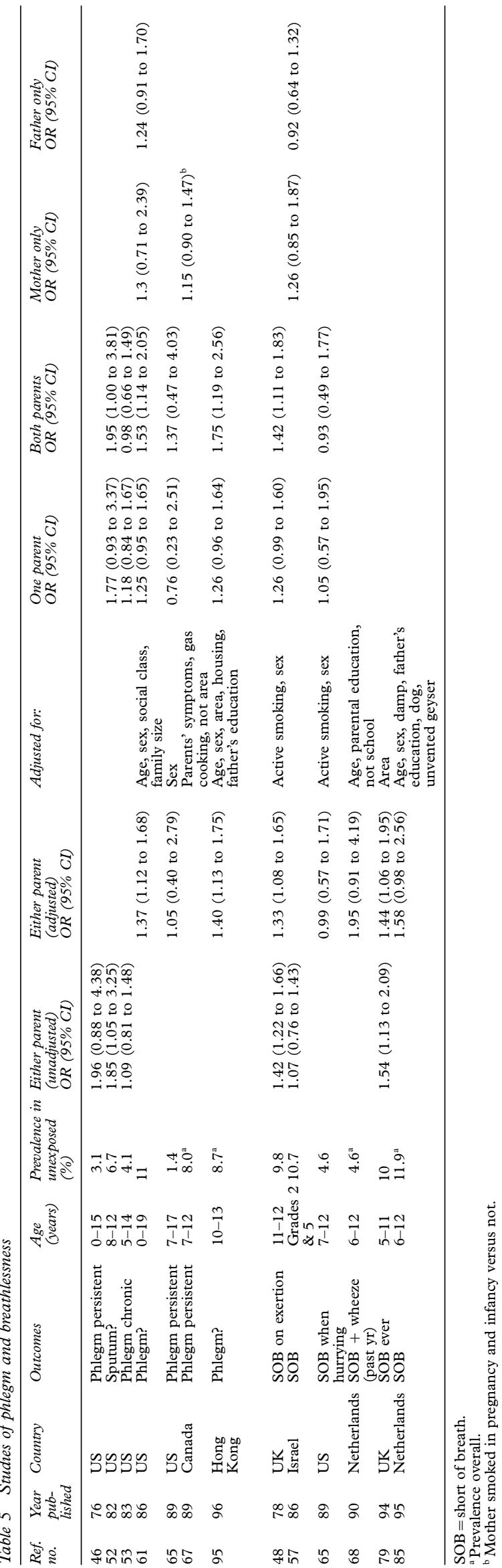


Table 6 Summary of pooled random effects odds ratios with 95\% confidence intervals (number of studies in parentheses)

\begin{tabular}{|c|c|c|c|c|c|c|c|c|c|c|c|c|c|c|c|}
\hline & \multicolumn{3}{|c|}{ Either parent smokes } & \multicolumn{3}{|c|}{ One parent smokes } & \multicolumn{3}{|c|}{ Both parents smoke } & \multicolumn{3}{|c|}{ Mother only smokes } & \multicolumn{3}{|c|}{ Father only smokes } \\
\hline & $O R$ & $(95 \% C I)$ & $(n)$ & $O R$ & $(95 \% C I)$ & $(n)$ & $O R$ & $(95 \% C I)$ & (n) & $O R$ & $(95 \% C I)$ & (n) & $O R$ & $(95 \% C I)$ & $(n)$ \\
\hline Ast & 1.21 & (1.10 to 1.34$)$ & $(21)^{a}$ & 1.04 & (0.78 to 1.38$)$ & (6) & 1.50 & (1.29 to 1.73$)$ & (8) & 1.36 & (1.20 to 1.55$)$ & (11) & 1.07 & to 1.24 ) & (9) \\
\hline Wheeze\# & 1.24 & (1.17 to 1.31$)$ & $(30)^{a}$ & 1.18 & (1.08 to 1.29$)$ & (11) & 1.47 & (1.14 to 1.90$)$ & (11) & 1.28 & (1.19 to 1.38 ) & $(18)^{\mathrm{b}}$ & 1.14 & (1.06 to 1.23$)$ & (10) \\
\hline Cough & 1.40 & (1.27 to 1.53$)$ & $(30)^{a}$ & 1.29 & (1.11 to 1.51 ) & (15) & 1.67 & (1.48 to 1.89 ) & (16) & 1.40 & (1.20 to 1.64$)$ & $(14)^{\mathrm{b}}$ & 1.21 & (1.09 to 1.34$)$ & (9) \\
\hline Phlegm* & 1.35 & (1.13 to 1.62$)$ & (6) & 1.25 & (0.97 to 1.63$)$ & (5) & 1.46 & (1.04 to 2.05$)$ & (5) & & & & & & \\
\hline Breathlessness* & 1.31 & (1.08 to 1.59$)$ & (6) & & & & & & & & & & & & \\
\hline
\end{tabular}

\# Excluding EC study, in which the pooled odds ratio was 1.20 .

* Data for phlegm and breathlessness restricted as several comparisons are based on fewer than five studies.

${ }^{a}$ Two age groups for reference 80 included as separate studies.

${ }^{\mathrm{b}}$ Reference 82 included as three separate studies.

at the effects of change in smoking habit on symptoms longitudinally.

\section{EFFECT OF PARENTAL SMOKING AT DIFFERENT AGES}

For a given level of parental smoking, the odds ratios reported in this review of school children are somewhat lower than those we found in our review of the effects of parental smoking on lower respiratory illness in infancy and early childhood where the pooled odds ratio for either parent smoking was 1.57 (95\% CI 1.42 to 1.74$).{ }^{6}$ While this is consistent with previous claims of smaller effects in older children, the contrast is less marked than has been suggested. ${ }^{4}$ Moreover, it is clearly important to consider the level of exposure when comparing estimates of effect which some previous reviews have not done. ${ }^{5}$ For the same level of maternal smoking, exposure to environmental tobacco smoke as assessed by cotinine levels declines markedly between infancy and school age. ${ }^{11}$

Even after school entry there is evidence that exposure (as assessed by salivary cotinine levels) continues to fall and there is evidence of both differential exposure by sex and by geographical area and time of year. ${ }^{110112113}$ This fall in cotinine with age is consistent with data from the large nationwide US study ${ }^{88}$ which strongly suggests that the adverse effect of parental smoking on respiratory symptoms in their children falls with age even amongst school children. This may reflect reduction in exposure because they are spending less time with their parents, or to maturation of the respiratory system, or both.

\section{PUBLICATION BIAS}

There is clear evidence of publication bias, particularly for wheeze, in that small studies were only published if they had high odds ratios. However, this will have had minimal effect on our pooled estimates of odds ratios unless publication bias also existed for larger studies. The data from the EC study are reassuring in this respect because they were not subject to publication bias. The odds ratio for wheeze ever from the EC studies based on some 22000 children is almost identical to that from our analysis of studies published in journals.

\section{Conclusions}

The effects of passive smoke exposure in childhood on the prevalence of respiratory symptoms and asthma are not due to chance and cannot be explained by publication bias or residual confounding with environmental factors. While the relative odds are somewhat smaller than the effects of passive smoking on lower respiratory disease (including wheezing illnesses) in infancy, they apply to common symptoms and the public health burden is thus large.

The prevalence of symptoms ascertained by cross-sectional surveys is determined by both disease incidence and prognosis, and the pattern of morbidity tends to be dominated by a large number of children with relatively mild symptoms. There are indications that exposure to environmental tobacco smoke has a greater effect on more severe wheeze, both within studies where odds ratios were reported for different severity measures and between studies where odds ratios were highest in studies with low prevalence rates of wheeze. Later in this series of systematic reviews we examine data from longitudinal and case-control studies of asthma and wheezing illness in order to distinguish more clearly the effects of parental smoking on measures of incidence, prognosis, and disease severity.

This review was commissioned by the Department of Health The views expressed are those of the authors and are no necessarily those of the Department of Health. We are indebted to Jenny Taylor and Claire Chazot for their diligent work in assembling the relevant literature and to Iain Carey for assistance with the figures.

1 Norman-Taylor W, Dickinson VA. Danger for children in smoking families. Community Med 1972;128:32-3.

2 Colley JR, Holland WW, Corkhill RT. Influence of passive smoking and parental phlegm on pneumonia and bronchitis in early childhood. Lancet 1974;ii:1031-4.

3 Colley JR. Respiratory symptoms in children and parenta smoking and phlegm production. BMF 1974;2:201-4.

4 US Department of Health and Human Services, US Environmental Protection Agency. Respiratory health effects of passive smoking: lung cancer and other disorders. NIH Publication No. 93-3605, August 1993, 230-42.

5 DiFranza JR, Lew RA. Morbidity and mortality in children associated with the use of tobacco products by other associated with the use of tobacco

6 Strachan DP, Cook DG. Health effects of passive smoking - 1. Parental smoking and lower respiratory illness in infancy and early childhood. Thorax 1997;52:905-14.

infancy and early childhood. Thorax 1997;52:905-14.
7 von Mutius E, Sherrill DL, Fritzsch C, Martinez FD, Lebowitz MD. Air pollution and upper respiratory sympLebowitz MD. Air pollution and upper respiratory symp-
toms in children from East Germany. Eur Respir $\mathcal{F} 1995$; toms in chilc

8 Wilkie AT, Ford RP, Pattemore P, Schluter PJ, Town I, Graham P. Prevalence of childhood asthma symptoms in an industrial suburb of Christchurch. NZ Med f 1995 108:188-90.

9 Weiland SK, Mundt KA, Ruckmann A, Keil U. Selfreported wheezing and allergic rhinitis in children and 
traffic density on street of residence. Ann Epidemiol 1994; 4:243-7.

10 Stern BR, Raizenne ME, Burnett RT, Jones L, Kearney J, Franklin CA. Air pollution and childhood respiratory health: exposure to sulfate and ozone in 10 Canadian rural communities. Environ Res 1994;66:125-42.

11 Guneser S, Atici A, Alparslan N, Cinaz P. Effects of indoor environmental factors on respiratory systems of children. 7 Trop Pediatr 1994;40:114-6.

12 Porro E, Calamita P, Rana I, Montini L, Criscione S. Atopy and environmental factors in upper respiratory infections: an epidemiological survey on 2304 school
children. Int 7 Pediatr Otorhinolaryngol 1992;24:111-20.

13 Terblanche AP, Opperman L, Nel CM, Reinach SG, Tosen G, Cadman A. Preliminary results of exposure measurements and health effects of the Vaal Triangle Air urements and health effects of the Vaal Triangle A
Pollution Health Study. $S$ Afr Med $F$ 1992;81:550-6.

14 Dotterud LK, Kvammen B, Bolle R, Falk ES. A survey of atopic diseases among school children in Sor-Varanger community. Possible effects of subarctic climate and industrial pollution from Russia. Acta Dermato-Venereol 1994;74:124-8.

15 Coetzee AM, Smith FCA, Van der Merwe CA, Dreyer RJ. The influence of air pollution on health in the Sasolburg area. S Afr Med f 1986;70:339-43.

16 Pengelly LD, Kerigan AT, Goldsmith $\mathrm{CH}$, Inman EM. The Hamilton study: distribution of factors confounding
the relationship between air quality and respiratory health. f Air Poll Control Ass 1984;34:1039-43.

17 Kelly YJ, Brabin BJ, Milligan P, Heaf DP, Reid J, Pearson MG. Maternal asthma, premature birth, and the risk of respiratory morbidity in schoolchildren in Merseyside. respiratory morbidity in
Thorax 1995;50:525-30.

18 Flynn MG. Respiratory symptoms of rural Fijian and Flynn MG. Respiratory symptoms of rural Fijian

19 Kalyoncu AF, Selcuk ZT, Karakoca Y, Emri AS, Coplu L, Sahin AA, et al. Prevalence of childhood asthma and allergic diseases in Ankara, Turkey. Allergy 1994;49: 485-8.

20 Ugnat AM, Mao Y, Miller AB, Wigle DT. Effects of residential exposure to environmental tobacco smoke on Canadian children. Can F Public Health 1990;81:345-9.

21 Clifford RD, Radford M, Howell JB, Holgate ST. Prevalence of respiratory symptoms among 7 and 11 year
old schoolchildren and association with asthma. Arch Dis Child 1989;64:1118-25.

22 Spinaci S, Arossa W, Bugiani M, Natale P, Bucca C, de Candussio G. The effects of air pollution on the respiratory health of children: a cross-sectional study. Pediatr Pulmonol 1985;1:262-6.

23 De Kok ME, Mertens PLJM, Cuijpers CEJ, Swaen GMH, Wesseling GJ, Broer J, et al. The rate of respiratory symptoms among primary school children in two Dutch symptoms among primary school childr.

24 Viegi G, Paoletti P, Carrozzi L, Vellutini M, Diviggiano E, Di Ped C, et al. Prevalence rates of respiratory symptoms in Italian general population samples exposed to different levels of air pollution. Environ Health Perspect 1991;94:

25 Le Roux P, Bourderont D, Loisel I, Collet A, Boulloche $\mathrm{J}$, Briquet MT, et al. Epidemiology of infantile asthma in the Le Havre region. Arch Pediatr 1995;2:643-9.

26 Sennhauser FH, Guntert BJ. Prevalence of bronchial asthma in childhood in Switzerland: significance of symptoms and diagnosis. Schweiz Med Wochenschr 1992;122: 189-93.

27 Aubry C, Teculescu D, Chau N, Viaggi MN, Pham QT, Manciaux M. Respiratory health of children and atmospheric pollution. I. Respiratory symptoms. Rev Mal Respir 1989;6:215-20.

28 Melia RJ, Florey C, du V, Morris RW, Goldstein BD, John $\mathrm{HH}$, Clark D, et al. Childhood respiratory illness and the home environment. II. Association between respiratory illness and nitrogen dioxide, temperature and relative humidity. Int f Epidemiol 1982;11:164-9.

29 Gepts L, Borlee I, Minette A. Prevalence of respiratory symptoms in 1659 school children living in a non polluted area. Acta Tuberc Pneumol Belg 1978;69:179-210.

30 Gold DR, Rotnitzky A, Damokosh AI, Ware JH, Speizer FE, Ferris BG, et al. Race and gender differences in respiratory illness prevalence and their relationship to environmental exposures in children 7 to 14 years of age. Am Rev Respir Dis 1993;148:10-18.

31 Rona RJ, Chinn S. Lung function, respiratory illness, and passive smoking in British primary school children. Thorax 1993;48:21-5

32 Brunekreef B. Associations between questionnaire reports of home dampness and childhood respiratory symptoms. Sci Total Environ 1992;127:79-89. 33 Goren AI, Hellman S. Passive smoking among school-

34 Strachan DP, Jarvis MJ, Feyerabend C. The relationship of salivary cotinine to respiratory symptoms, spirometry, and exercise-induced bronchospasm in seven-year-old children. Am Rev Respir Dis 1990;142:147-51.

35 Kuehr J, Frischer T, Karmaus W, Meinert R, Barth R, Urbanek R. Clinical atopy and associated factors in primary-school pupils. Allergy 1992;47:650-5.

36 Kungskulniti N, Pulket C, Miller FD, Smith KR. Solid waste scavenger community: an investigation in Bangkok, Thailand. Asia-Pacific f Public Health 1991;5:54-65.

37 Love GJ, Lan SP, Shy CM. A study of acute respiratory disease in families exposed to different levels of air pollution in the Great Salt Lake basin, Utah, 1971-1972
38 Yarnell JW, St Leger AS. Respiratory illness, maternal smoking habit and lung function in children. $\mathrm{Br} f \mathrm{Di}$ Chest 1979;73:230-6.

39 Azizi BH, Henry RL. The effects of indoor environmenta factors on respiratory illness in primary school children in Kuala Lumpur. Int f Epidemiol 1991;20:144-50.

40 Tsimoyianis GV, Jacobson MS, Feldman JG, AntonioSantiago MT, Clutario BC, Nussbaum $M$, et al. Reduction in pulmonary function and increased frequency of cough associated with passive smoking in teenage athletes. Pediatrics 1987;80:32-6.

41 Feldman JG, Tsimoyianis GV, Shenker IR, Nussbaum M, Jacobson MS. Adverse pulmonary effects of involuntary smoking in adolescent athletes: a confirmation. Children' Hospital Quarterly 1990;2:287-90.

42 Bener A, al-Jawadi TQ, Ozkaragoz F, Anderson JA. Prevalence of asthma and wheeze in two different climatic areas of Saudi Arabia. Indian F Chest Dis Allied Sci 1993 35:9-15.

43 al-Frayh Bener AR, Facharzt AR, al-Jawadi TQ. Parental smoking and the risk of childhood asthma. F Asthma 1991;28:281-6.

44 al Frayh Bener AR. Asthma patterns in Saudi Arabian children. $\mathcal{F} R$ Soc Health 1990;110:98-100.

45 al-Frayh Bener AR, Ozkaragoz F, al-Jawadi TQ. Passive smoking effects on wheezy bronchitis. Ann Saudi Med 1993;13:222-5.

46 Lebowitz MD, Burrows B. Respiratory symptoms related to smoking habits of family adults. Chest 1976;69:48-50

47 Schilling RS, Letai AD, Hui SL, Beck GJ, Schoenberg JB, Bouhuys A. Lung function, respiratory disease, and smoking in families. Am F Epidemiol 1977;106:274-83.

48 Bland M, Bewley BR, Pollard V, Banks MH. Effect of children's and parents' smoking on respiratory symptoms. Arch Dis Child 1978;53:100-5.

49 Stanhope JM, Rees RO, Mangan AJ. Asthma and wheeze in New Zealand adolescents. NZ Med f 1979;90:279-82.

50 Kasuga H, Hasebe A, Osaka F, Matsuki H. Respiratory symptoms in school children and the role of passive smoking. Tokai f Exp Clin Med 1979;4:101-14.

51 Weiss ST, Tager IB, Speizer FE, Rosner B. Persistent wheeze. Its relation to respiratory illness, cigarette smoking, and level of pulmonary function in a population sample of children. Am Rev Respir Dis 1980;122:697-707.

52 Dodge R. The effects of indoor pollution on Arizon children. Arch Environ Health 1982;37:151-5.

53 Schenker MB, Samet JM, Speizer FE. Risk factors for childhood respiratory disease. The effect of host factors and home environmental exposures. Am Rev Respir Dis 1983;128: $1038-43$.

54 Ekwo EE, Weinberger MM, Lachenbruch PA, Huntley WH. Relationship of parental smoking and gas cooking to respiratory disease in children. Chest 1983;84:662-8.

55 Charlton A. Children's coughs related to parental smoking. BMF 1984;288:1647-9.

56 Ware JH, Dockery DW, Spiro A, Speizer FE, Ferris BG Passive smoking, gas cooking, and respiratory health of children living in six cities. Am Rev Respir Dis 1984;129. 366-74.

57 Goren AI, Goldsmith JR. Epidemiology of childhood respiratory disease in Israel. Eur $\mathcal{F}$ Epidemiol 1986;2:139-50.

58 Park JK, Kim IS. Effects of family smoking on acute respiratory disease in children. Yonsei Med 7 1986;27: 261-70.

59 McConnochie KM, Roghmann KJ. Breast feeding and maternal smoking as predictors of wheezing in children age 6 to 10 years. Pediatr Pulmonol 1986;2:260-8.

60 Strachan DP, Elton RA. Relationship between respiratory morbidity in children and the home environment. Family Pract 1986;3:137-42.

61 Burchfiel CM, Higgins MW, Keller JB, Howatt WF, Butler WJ, Higgins IT. Passive smoking in childhood. Respiratory conditions and pulmonary function in Tecumseh, Michigan. Am Rev Respir Dis 1986;133:966-73.

62 Strachan DP. Damp housing and childhood asthma: validation of reporting of symptoms. BMF 1988;297:1223-6.

63 Somerville SM, Rona RJ, Chinn S. Passive smoking and respiratory conditions in primary school children. $\mathcal{f}$ Epidemiol Community Health 1988;42:105-10.

64 Andrae S, Axelson O, Bjorksten B, Fredriksson M, Kjellman NI. Symptoms of bronchial hyperreactivity and asthma in relation to environmental factors. Arch Dis Child 1988;63:473-8.

65 Hosein HR, Corey P, Robertson JM. The effect of domestic factors on respiratory symptoms and $\mathrm{FEV}_{1}$. Int $\mathcal{F}$ Epidemiol 1989;18:390-6.

66 Stern B, Jones L, Raizenne M, Burnett R, Meranger JC, Franklin CA. Respiratory health effects associated with ambient sulfates and ozone in two rural Canadian communities. Environ Res 1989;49:20-39.

67 Stern B, Raizenne M, Burnett R. Respiratory effects of early childhood exposure to passive smoke. Environ Int 1989;15:29-34

68 Dijkstra I, Houthuijs D, Brunekreef B, Akkerman I, Boleij JS. Respiratory health effects of the indoor environment in a population of Dutch children. Am Rev Respir Dis in a population of

69 Henry RL, Abramson R, Adler JA, Wlodarcyzk J, Hensley MJ. Asthma in the vicinity of power stations: I. A prevalence study. Pediatr Pulmonol 1991;11:127-33.

70 Chinn S, Rona RJ. Quantifying health aspects of passive smoking in British children aged 5-11 years. $\mathcal{F}$ Epidemio Community Health 1991;45:188-94. 
71 Dekker C, Dales R, Bartlett S, Brunekreef B, Zwanenburg H. Childhood asthma and the indoor environment. Chest 1991;100:922-6.

72 Forastiere F, Corbo GM, Michelozzi P, Pistelli R, Agabiti $\mathrm{N}$, Brancato $\mathrm{G}$, et al. Effects of environment and passive smoking on the respiratory health of children. Int $\mathcal{f}$ Epidemiol 1992;21:66-73.

73 Duffy DL, Mitchell CA. Lower respiratory tract symptoms in Queensland schoolchildren: risk factors for wheeze, cough and diminished ventilatory function. Thorax 1993; 48:1021-4.

74 Schmitzberger R, Rhomberg K, Buchele H, Puchegger R, Schmitzberger-Natzmer D, Kemmler G, et al. Effects of air pollution on the respiratory tract of children. Pediatr air pollution on the resp

75 Jenkins MA, Hopper JL, Flander LB, Carlin JB, Giles GG The associations between childhood asthma and atopy, and parental asthma, hay fever and smoking. Paediatr Perinatal Epidemiol 1993;7:67-76.

76 Halliday JA, Henry RL, Hankin RG, Hensley MJ. Increased wheeze but not bronchial hyper-reactivity near power stations. I Epidemiol Community Health 1993;47: $282-6$.

77 Soto-Quiros M, Bustamante M, Gutierrez I, Hanson LA, Strannegard IL, Karlberg J. The prevalence of childhood asthma in Costa Rica. Clin Exp Allergy 1994:24:1130-6.

78 Shaw R, Woodman K, Crane J, Moyes C, Kennedy J, Pearce N. Risk factors for asthma symptoms in Kawerau children. NZ Med f 1994;107:387-91.

79 Brabin B, Smith M, Milligan P, Benjamin C, Dunne E, Pearson M. Respiratory morbidity in Merseyside schoolchildren exposed to coal dust and air pollution. Arch Dis Child 1994:70:305-12.

80 Moyes CD, Waldon J, Ramadas D, Crane J, Pearce N. Respiratory symptoms and environmental factors in schoolchildren in the Bay of Plenty. NZ Med f 1995;108: 358-61

81 Lau YL, Karlberg J, Yeung CY. Prevalence of and factors associated with childhood asthma in Hong Kong. Acta Paediatr 1995;84:820-2.

82 Braback L, Breborowicz A, Julge K, Knuttson A, Riikjarv MA, Vasar M, et al. Risk factors for respiratory symptoms and atopic sensitisation in the Baltic area. Arch Dis Child 1995;72:487-93.

83 Volkmer RE, Ruffin RE, Wigg NR, Davies N. The prevalence of respiratory symptoms in South Australian prevalence of respiratory symptoms in South Australian pre-
school children. II. Factors associated with indoor air quality. I Paediatr Child Health 1995;31:116-20.

84 Guality. F Paediatr Child Health 1995;31:116-20. schoolchildren and their relationship to environmental schoolchildren and their relationship to environmental Environ Health 1995;50:112-8.

85 Cuijpers CE, Swaen GM, Wesseling G, Sturmans F, Wouters EF. Adverse effects of the indoor environment on respiratory health in primary school children. Environ Res 1995;68:11-23.

86 Kay J, Mortimer MJ, Jaron AG. Do both paternal and maternal smoking influence the prevalence of childhood asthma? A study into the prevalence of asthma in children and the effects of parental smoking. F Asthma 1995;32: 47-55.

87 Soyseth V, Kongerud J, Boe J. Postnatal maternal smoking increases the prevalence of asthma but not of bronchial hyperresponsiveness or atopy in their children. Chest hyperresponsiveness

88 Stoddard JJ, Miller T. Impact of parental smoking on the prevalence of wheezing respiratory illness in children. Am prevalence of wheezing respira
$\mathcal{F}$ Epidemiol 1995;141:96-102.

89 Ninan TK, Macdonald L, Russell G. Persistent nocturnal cough in childhood: a population based study. Arch Dis Child 1995;73:403-7.

90 Wright AL, Holberg CJ, Morgan WJ, Taussig LM, Halonen $M$, Martinez FD. Recurrent cough in childhood and its relation to asthma. Am F Respir Crit Care Med 1996;153: 1259-65.

91 Beckett WS, Belanger K, Gent JF, Holford TR, Leaderer BP. Asthma among Puerto Rican Hispanics: a multi- ethnic comparison study of risk factors. Am F Respir Crit Care Med 1996;154:894-9.

92 Bener A, Abdulrazzaq YM, Al-Mutawwa J, Debuse P. Genetic and environmental factors associated with asthma. Hum Biol 1996;68:405-14.

93 Zejda JE, Skiba M, Orawiec A, Dybowska T, Cimander B. Respiratory symptoms in children of upper silesia, poland: cross-sectional study in two towns of differen air pollution levels. Eur f Epidemiol 1996;12:115-20.

94 Chen Y, Rennie DC, Dosman JA. Influence of environmental tobacco smoke on asthma in nonallergic and allergic children. Epidemiology 1996;7:536-9.

95 Peters J, Hedley AJ, Wong CM, Lam TH, Ong SG, Liu $\mathrm{J}$, et al. Effects of an ambient air pollution intervention and environmental tobacco smoke on children's respiratory environmental tobacco smoke on children's respiratory

96 Abuekteish F, Alwash R, Hassan M, Daoud AS. Prevalence of asthma and wheeze in primary school children in
Northern Jordan. Ann Trop Paediatr 1996;16:227-31.

97 Austin JB, Russell G. Wheeze, cough, atopy, and indoor environment in the Scottish Highlands. Arch Dis Child 1997;76:22-6.

98 Leung R, Wong G, Lau J, Ho A, Chan JKW, Choy D, et al. Prevalence of asthma and allergy in Hong Kong schoolchildren: An ISAAC study. Eur Respir f 1997;10 354-60

99 Selcuk ZT, Caglar T, Enunlu T, Topal T. The prevalence of allergic diseases in primary school children in Edirne, Turkey. Clin Exp Allergy 1997;27:262-9.

100 Farber HJ, Wattigney W, Berenson G. Trends in asthma prevalence: The Bogalusa heart study. Ann Allergy Asthm Immunol 1997; 78:265-9.

101 Florey C du V, Swan AV, van der Lende R, Holland WW, Berlin A, Ferrante E Di. Report on the EC epidemiological survey of the relationship between air pollution and respiratory health in primary school children. Brussels: Commission of the European Communities, 1993.

102 Vedal S, Schenker MB, Samet JM, Speizer FE. Risk factors for childhood respiratory disease. Analysis of pulmonary for childhood respiratory disease. Analysis of pulm

103 Stern BR, Raizenne ME, Burnett RT, Jones L, Kearney J, Franklin CA. Air pollution and childhood respiratory Franklin CA. Air pollution and childhood respiratory health: exposure to sulfate and ozone in 10 Canal communities. Environ Res 1994;66:125-42.

104 Goren AI, Hellman S. Passive smoking among schoolchildren in Israel. Environ Health Perspect 1991;96:203-11.

105 Colley JRT, Brasser LJ, eds. Chronic respiratory disease in children in relation to air pollution. Report on a WHO study. EURO Reports and Studies 28. Copenhagen: World Health Organisation, 1980

106 Medical Research Council. Questionnaire on respiratory symptoms. London: Medical Research Council, 1966.

107 Ferris BG. Epidemiology standardization project. Am Rev Respir Dis 1978;118(Suppl):1-120.

108 Asher MI, Keil U, Anderson HR, Beasley R, Crane J, Martinez $\mathrm{F}$, et al. International study of asthma and allergies in childhood (ISAAC): rationale and methods. Eur Respir f 1995;8:483-91.

109 Breslow N, Day NE. Statistical methods in cancer research. Volume 1: The analysis of case-control studies. Lyon: International Agency for Research on Cancer, 1980:142.

110 Cook DG, Whincup PH, Jarvis MJ, Strachan DP, Papacosta O, Bryant A. Passive exposure to tobacco smoke in children aged 5-7: individual, family and community factors. BMf 1994;308:384-9.

111 Irvine L, Crombie IK, Clark RA, Slane PW, Goodman KE, Feyerabend C, Cater JI. What determines levels of passive smoking in children with asthma? Thorax 1997, 52:766-9.

112 Jarvis MJ, Strachan DP, Feyerabend C. Determinants of passive smoking in children in Edinburgh, Scotland. $A m$ F Public Health 1992;82:1225-9.

113 Pirkle JL, Flegal KM, Benart JT, Brody DJ, Etzel RA, Maurer KR. Exposure of the US population to environmental tobacco smoke: the Third National Health and Nutrition survey 1988 to 1991. FAMA 1996;275: $1233-40$. 